\title{
Indonesian Equity Fund Performance Determinants
}

\author{
Raden Budi Ginanjar ${ }^{1}$, Augustina Kurniasih ${ }^{2}$ \\ \{budiginanjar83@gmail.com¹, augustina.kurniasih@mercubuana.ac.id ${ }^{2}$ \}
}

Master of Management, Postgraduate Program, Universitas Mercu Buana, Jakarta, Indonesia ${ }^{12}$

\begin{abstract}
Investors have challenges to choose mutual funds that consistently perform best due to facing many choices and different returns of mutual funds as an investment instrument. This research was conducted to find out the determinants of the equity mutual funds' performance with a modern portfolio analysis approach which is the development of portfolio theory put forward by Markowitz. This study uses multiple linear regression methods are used to answer the research problem and the purposive sampling technique to select 282 sample Indonesian Rupiah-denominated equity mutual funds data in the form of characteristics and performance of equity mutual funds throughout 2019. The results showed that the ability of investment managers to conduct stock selection has a positive and significant effect while the ability of investment managers in terms of market timing shows a negative and significant effect on the performance of equity mutual fund as measured by Treynor Measure and Sharpe Ratio. Other results show that the age of a mutual fund both have a negative impact to the performance of equity mutual funds in 2019 as measured by the Sharpe Ratio approach, while the size of the equity mutual fund has no impact to both measurements of the performance of equity mutual funds. This research is expected to particularly contribute to mutual fund investors in terms of selecting good-performing equity mutual funds and for investment managers in determining the company's strategy in managing investor funds in the form of mutual funds.
\end{abstract}

Keywords: Market Timing, Stock Selection, Performance, Mutual Fund, Risk and Return

\section{Introduction}

Investment is defined as a commitment to cash and other assets in the present to get benefits in the future [1]. Investors currently can choose various types of investment instruments, both financial and non-financial investment instruments. One instrument that can be an investment choice is the Mutual Fund. Investing through mutual fund securities instruments is a logical choice because investing mutual funds indirectly invests in capital market instruments with professional management assistance which is investment managers [2]. Mutual funds are designed as an instrument to raise funds from the public especially small investors, and investors who do not have much time and expertise to calculate the risk of their investment [3].

Data from the Financial Services Authority-(Otoritas Jasa Keuangan-OJK) (2019) shows a significant growth in terms of the number of mutual funds and the total value of assets under management to grow by $257.5 \%$ and $262.8 \%$ since the end of 2010 to September 2019 . Investment managers which manage funds including mutual fund total of 92 investment management companies as of September 2019. Facing that many choices and different returns 
of mutual funds as an investment instrument, it becomes a challenge for investors to choose mutual funds that consistently perform best.

\subsection{Literature review}

Investment portfolio theory guides investors or financial planners to allocate money and other capital assets in investment portfolios [4]. Accordingly, investment theories that have undergone evolutionary developments over time can be used as a reference or guideline by investment practitioners or investors in performing investment management. Modern Portfolio Theory was developed by Harry Markowitz that proposed the theory of "portfolio choice" in which the investor analyzes risk relative to the expected return [5]. Then this theory was developed by Treynor, Sharpe and Litner by introducing the Capital Assets Pricing Model (CAPM). CAPM explains the trade-off or exchange between asset returns and risks, measuring the risk of an asset as the covariance of the asset's return with overall returns on the market [29]. Based on portfolio theory and CAPM, there are indicators used to measure portfolio performance that considers risk adjusted returns. There are 4 (four) measurements for the performance of equities portfolios that combine return and risk performance in one value, which are the measurement of portfolio performance Treynor, Sharpe, Jensen and Information Ratio [6]. Meanwhile, Bodie et al argue that Jensen's measurement as Alpha $(\alpha)$ of an investment [1].

Many factors affect the performance of mutual funds and interesting to understand the factors that affect the performance of mutual funds. Current research results on factors that affect the performance of mutual funds seem to update the results of research that have been done several decades earlier as done by Treynor and Mazuy [7] and Henriksson [8] whose both empirical result show does not support the hypothesis that investment managers can run successful investment strategies which can improve mutual fund performance. As support by Ahmad et al that large-sized mutual funds enjoy several benefits [9]. Table 1 shows previous research on factors that affect mutual fund performance, especially stock selection capability, market timing ability, mutual fund size and mutual fund age, still shows the research results have not yet pursed the same conclusion. Accordingly, giving opportunities to conduct research related to matters that affect mutual fund performance.

Table 1 Previous Research Results

\begin{tabular}{cccccc}
\hline Reference & $\begin{array}{c}\text { Research } \\
\text { Location }\end{array}$ & $\begin{array}{c}\text { Stock Selection } \\
\text { Ability }\end{array}$ & $\begin{array}{c}\text { Market } \\
\text { Timing } \\
\text { Ability }\end{array}$ & $\begin{array}{c}\text { Fund } \\
\text { Size }\end{array}$ & $\begin{array}{c}\text { Fund } \\
\text { Age }\end{array}$ \\
\hline$[2]$ & Pakistan & N/A & N/A & - & $\Theta$ \\
{$[3]$} & Indonesia & N/A & N/A & + & $\Theta$ \\
{$[4]$} & Indonesia & N/A & N/A & $\Theta$ & + \\
{$[6]$} & Taiwan & + & - & N/A & N/A \\
{$[9]$} & Germany & - & + & N/A & N/A \\
{$[12]$} & United States & N/A & N/A & - & $\Theta$ \\
{$[12]$} & N countries Asia-Europe & N/A & N/A & + & - \\
{$[14]$} & Indonesia & + & $\Theta$ & $\Theta$ & N/A \\
{$[22]$} & India & $\Theta$ & $\Theta$ & N/A & N/A \\
{$[34]$} & Indonesia & + & - & $\Theta$ & N/A \\
\hline
\end{tabular}

Note: Positive Effect (+); Negative Effect (-); No Effect ( $($ ); Not Examined (N/A) 
Hypothesis that the stock selection ability, the market timing ability, the fund size and the fund age each of them has a positive effect on the equity mutual funds' performance are constructed for this research, based on following research results. From a social point of view, it is important to know whether mutual fund investment managers add value to the portfolios they manage [10]. The assessment of mutual fund performance is based on two capabilities, which are stock selection and market timing capabilities. There are two (2) attributes of expertise needed to assess the performance of investment managers, the ability to achieve above-average returns for certain levels of risk and the ability to diversify portfolios optimally to eliminate all unsystematic risk relative to portfolio benchmarks [6].

The ability of stock selection which is defined as the ability to select the best assets with the same risk profile [11], the ability of mutual fund managers to beat benchmarks in terms of risk-adjusted [12]. Previous studies have shown that mutual fund performance is positively and significantly influenced by stock selection ability [13] [14]. While, market timing capability is the ability of mutual fund managers to correctly anticipate the direction of the aggregate movement of market fluctuations by entering a bullish market or exiting the bearish market [12]. Cuthbertson and Nitzsche concluded that the market timing ability of the investment manager positively influences mutual fund performance [15].

The fund size is measured by the value of assets under management or the value of net assets under management [16] or is defined as the total market value of all securities in the portfolio [17]. Ciccotello and Grant mention that large-sized mutual funds enjoy several benefits including having an economy of scale value and having greater opportunities compared to small-sized mutual funds to diversify potentially profitable investments [18]. The research result also showed that mutual fund performance was positively influenced by the size of the managed fund of the mutual fund [19]. While, the fund age is counted by years since the mutual fund starts operating [9]. The study result indicates that mutual fund performance is influenced by the mutual fund age [14].

\section{Research Method}

This research is a quantitative study with associative research methods to show empirical evidence of the effect of the independent variable on the performance of equity mutual funds. Factors affecting equity mutual funds' performance or independent variables of this study are stock selection and market timing abilities that represent investment manager attributes, as well as the fund size and the fund age as independent variables that represent mutual fund characteristics. Jensen Alpha as a constant measure of a portfolio reflects how much the ability of investment managers to attribute portfolio returns above the average risk adjusted return, therefore Jensen's measurement is expected to reflect the measurement of stock selection capability [6]. Accordingly, the ability of stock selection to be an independent variable in this study was calculated by measuring Jensen or Jensen Alpha as used by Lonkani, et al [20]. Jensen Alpha is a prototype of a single factor regression model to isolate the ability of investment managers in the form of an intercept (alpha) as shown in equation (1).

where:

$$
\alpha=\operatorname{Rp}-[\mathrm{Rf}+\beta(\mathrm{Rm}-\mathrm{Rf})]+\varepsilon \ldots \ldots(1)
$$

$\alpha \quad$ : Intercept which indicates stock selection ability of investment manager

Rp : Fund portfolio return 


$$
\begin{array}{ll}
\mathrm{Rm} & : \text { Stock market return } \\
\mathrm{Rf} & : \text { Risk free asset return } \\
\beta & : \text { Portfolio beta value } \\
\varepsilon & : \text { Random error }
\end{array}
$$

In this research, the independent variable of market timing ability is measured by TreynorMazuy model with considerations refer to previous studies, those are: (1) the model is able to explain the investment portfolio performance rather than market performance [21], (2) the Henriksson-Merton model has disadvantages compared to Treynor-Mazuy model. HenrikssonMerton model uses a portfolio beta that limited with choosing one of two values, were the level of risk associated with market returns at the time of a bullish market (upper beta) and when a bearish market (lower beta). While the risk level to the market is higher in line with higher risk premium, and not only divided into two values [22]. Market timing ability is represented by positive slope value in the Treynor-Mazuy model, which is approved in equation (2).

where:

$$
\mathrm{Rp}-\mathrm{Rf}=\alpha+\beta(\mathrm{Rm}-\mathrm{Rf})+\gamma(\mathrm{Rm}-\mathrm{Rf})+\varepsilon
$$

$\gamma \quad$ : Regression coefficient which indicates market timing ability of investment manager

Rp : Fund portfolio return

Rm : Stock market return

Rf : Risk free asset return

$\alpha \quad$ : Intercept which indicates stock selection ability of investment manager

$\beta \quad$ : Regression coefficient of excess market return or slope at bearish

$\varepsilon \quad$ : Random error

The Independent variable that represents mutual fund characteristics is Net Asset Value (NAV) or asset under management were calculation result of the mutual fund total assets after deducting all of their debts or liabilities. The NAV value is a measure of the fund size [16]. In other words, the size of a mutual fund is defined by NAV [17]. However, considering the NAV can reach trillions of Rupiah, as a common consideration related to the scale, the proxy for the fund size that will be used in this study is Logarithm of NAV (LogNAV) [23]. The use of LogNAV has been commonly used in previous studies such as in Ferreira et al [19]. Another independent variable is the fund age, representing the period of the mutual fund being managed since it was first launched. The fund age is measured by the number of years the mutual fund is managed from the date of launch until the end of 2019. Mutual fund performance measurement as an independent variable, measured by the risk adjusted return approach uses the Treynor Measure (TM) and Sharpe Ratio (SR) method. The formula used is as shown in equations (3) and (4).

Treynor Measure : $\mathrm{TM}=(\mathrm{Rp}-\mathrm{Rf}) / \beta \mathrm{p}$

Sharpe Ratio $\quad: S R=(R p-R f) / \sigma p$

where,

TM : Treynor Measure, reward to volatility Treynor model

SR : Sharpe Ratio, reward to variability Sharpe model

Rp : Fund portfolio return

$\mathrm{Rm} \quad$ : Stock market return 
Rf : Risk free asset return

$\beta p \quad$ : Portfolio beta as a risk benchmark

бp : Portfolio standard deviation as risk benchmark

Therefore, there will be a discussion of 2 (two) regression equation models, which are the Y1 model is a regression equation model with the dependent variable measured by Treynor Measure (TM) and Y2 model of the regression equation with the dependent variable as measured by Sharpe Ratio (SR) measurement. The regression equation used is given in equation (5).

where,

$$
\mathrm{Y}=\alpha+\beta_{1} \mathrm{X}_{1}+\beta_{2} \mathrm{X}_{2}+\beta_{3} \mathrm{X}_{3}+\beta_{4} \mathrm{X}_{4}+\varepsilon
$$

$\mathrm{Y} \quad$ : Mutual fund performance

$\alpha \quad:$ Constant

X1 : Stock selection ability measured by Jensen-Alpha

X2 : Market timing ability measured by Treynor-Mazuy

X3 : Fund size

$\mathrm{X} 4 \quad$ : Fund age

$\beta 1$ to $\beta 4$ : Regression coefficient of stock selection, market timing, fund size and fund age, respectively

$\varepsilon \quad$ : Random error

The research population is all equity funds published on the site www.investpro.id. The research sample was selected using the Purposive Sampling technique, namely Indonesian Rupiah-denominated equity funds. Obtained 282 mutual funds that meet the sample criteria. Research data is secondary data and acts cross-sectionally. Data is obtained by downloading relevant data related to mutual funds and available at www.investpro.id. Data is processed using multiple linear regression.

\section{Results and Discussion}

\subsection{Result}

The result of the classical assumption test shows that normality and heteroscedasticity assumptions for regression equation model Y1 have not been met. While the regression equation model $\mathrm{Y} 2$ assumption that has not been fulfilled is the normality assumption. In this regard, handling is carried out by transforming data using Natural Logarithms (Ln). Furthermore, the results of this study have finding out the determinants of the equity mutual funds' performance as detail explanation below. Testing results for the goodness of fit for regression models $\mathrm{Y} 1$ and $\mathrm{Y} 2$ are presented in Table 2, where both models are appropriate. Test results show the significance value of the model has an error less than 0.05 , accordingly collectively four independent variables (Stock Selection, Market Timing, Fund Size, and Fund Age) are suitable models to explain the variability of equity mutual fund performance.

Table 2 Regression Model Testing Results

\begin{tabular}{ccccc}
\hline Model & $\mathbf{R}$ & $\mathbf{R}^{\mathbf{2}}$ & $\mathbf{F}$ & Sig. \\
\hline $\mathbf{Y}_{\mathbf{1}}$ & 0,806 & 0,650 & 8,360 & 0,001 \\
\hline $\mathbf{Y}_{\mathbf{2}}$ & 0,625 & 0,391 & 4,012 & 0,012 \\
\hline
\end{tabular}


The $\mathrm{R}^{2}$ values for $\mathrm{Y} 1$ and $\mathrm{Y} 2$ models are 0.650 and 0.391 , respectively. Equity mutual fund performance variability measured by $\mathrm{TM}$ and $\mathrm{SR}$ can be explained with all four independent variables by $65.0 \%$ and $39.1 \%$, respectively. There are still $35 \%$ and $60.9 \%$ of other factors that affect equity mutual funds' performance by using TM approach and SR approach, respectively. It can be concluded that using Sharpe Ratio approach there are still more explanatory variables that are not yet included in the model to show factors that affect equity mutual fund performance. Testing results on the effect of each independent variable on the dependent variable of the two models are presented in Table 3, as reference to generate following regression models (model of $\mathrm{Ln}$ transformation data):

$\operatorname{LnY}_{1}=-6,966+1,818 \operatorname{LnX} 1-0,358 \operatorname{LnX} X_{2}+0,021 \operatorname{LnX}_{3}-0,295 \operatorname{LnX}_{4}$

$\mathrm{LnY}_{2}=-1,490+0,915 \operatorname{LnX} 1-0,441 \operatorname{LnX}{ }_{2}-0,002 \operatorname{LnX} 3-0,772 \operatorname{LnX}$

Table 3. Test Results of Independent Variables Effect on Mutual Fund Performance

\begin{tabular}{|c|c|c|c|c|c|c|}
\hline Model & \multicolumn{3}{|l|}{ Model Y1 } & \multicolumn{3}{|c|}{ Model Y 2} \\
\hline Variable & Coefficient & $\mathbf{T}$ & Sig./2 & Coefficient & $T$ & Sig./2 \\
\hline Constanta & $-6,966$ & $-1,970$ & $0,032 * *$ & $-1,490$ & $-0,490$ & 0,3145 \\
\hline Stock Selection & 1,818 & 4,317 & $0,000 * * *$ & 0,915 & 2,416 & $0,0115^{* *}$ \\
\hline Market Timing & $-0,358$ & $-1,716$ & $0,0515^{*}$ & $-0,441$ & $-2,125$ & $0,0220 * *$ \\
\hline Fund Size & 0,021 & 0,183 & 0,4285 & $-0,002$ & $-0,020$ & 0,4920 \\
\hline Fund Age & $-0,295$ & $-0,726$ & 0,2385 & $-0,772$ & $-1,987$ & $0,0290 * *$ \\
\hline
\end{tabular}

Table 3 shows that the model Y1 (Treynor Measure) constant is $-6,966$ and is significant. It can be explained that without the influence of any independent variable, equity mutual fund performance is lower by $-6,966$ units than the return of risk-free assets. The stock selection has a positive and significant effect. The stock selection regression coefficient is 1,818 , indicating that when the investment manager's stock selection ability increases by 1 unit, the performance of mutual funds will increase by 1,818 units. Market timing has a negative and significant effect. Market timing regression coefficient is -0.358 indicates the absence of investment manager's market timing ability who can improve equity mutual funds performance, accordingly any not timely decisions to enter market affects declining equity mutual fund performance by 0.358 units. In the Y1 model, the fund size and fund age have no significant effect on equity mutual fund performance.

The constant in model Y2 (Sharp Ratio) is -1.490 with a significance of 0.3145 , which means the constant has no meaning. The stock selection has a positive and significant effect. The value of stock selection regression coefficient is 2.146 indicates that when the investment manager's stock selection ability increases by one unit, equity mutual funds' performance will increase by 2.146 units. Market timing has a negative and significant effect. The value of the market timing regression coefficient is -2.125 indicates the absence of investment manager's market timing ability to improve equity mutual funds' performance. Every not timely decision to enter market affects equity mutual fund performance decreased by $2.125 \%$. In the Y2 model, the fund size does not significantly affect equity mutual fund performance. The fund age has a negative and significant effect. The fund age regression coefficient is $-0,772$, indicating that when a mutual fund increases by one year, its performance decreases by 0.772 units. 


\subsection{Discussion}

Research findings on stock selection ability have a positive and significant effect is in line with results of research by Gusni et al [13]. Those who state equity funds performance tends to fluctuate with factors that have a positive effect only on stock selection ability. The results of this research are also in line with the opinion that Jensen measurement as an Alpha of any investment-related with every performance measurement [1]. Fine stock selection ability indicates the ability of investment managers to choose the right stock for mutual fund portfolio thus can generate a higher return [13]. The market timing ability of investment managers has a negative effect on mutual fund performance in both $\mathrm{Y} 1$ and $\mathrm{Y} 2$ modeling. A positive market timing coefficient indicates the ability to be punctual in entering the market [24].

Conversely, the negative market timing coefficient indicates that investment managers are not timely in entering the market. Findings of this research are that market timing has a negative effect in line with the results research which shows the lack of market timing capability in the mutual fund industry in Croatia, both with the Treynor-Mazuy model or the Henriksson-Merton model [25]. Literature study explains that the Treynor-Mazuy model and the Henriksson-Merton model are general models with an unconditional model approach that assumes all information available in the market and needs to use other approaches for better understanding on market timing ability, namely conditional model approach which calculates macroeconomic factors that affect the capital market [14]. As also stated by Chen et al that investment managers are more likely to focus on conducting micro-analysis to select stock that can provide higher returns compared to macro analysis such as market forecasting [14].

Model Y1 (TM) is able to measure reward to volatility for determining mutual fund performance with market risk (systematic risk), while Model Y2 (SR) is a reward to variability measurement to find out mutual fund performance with total risk (systematic risk and unsystematic risk). Even though the two models have not been tested differently, it can be considered a research conclusion which states that if the value of Jensen Alpha as a stock selection ability measurement is not statistically significant, mutual funds will have the same performance as the market portfolio [26].

In this result stock selection (Jensen Alpha) has a positive and statistically significant effect, so that equity mutual funds' performance is different from market portfolio performance in both Y1 and Y2 models. Jaksic et al also stated that if the portfolio is well diversified, performance measures of mutual funds will provide the same results with TM or SR because the total risk is the same as systematic risk [26]. The results of this research indicate that model Y1 (TM) has a higher ability to explain than model Y2 (SR). This indicates that diversification is not optimal and indicates the presence of non-systematic risk. Furthermore, observing the effect of X1 (stock selection) on Y1 modeling and Y2 modeling, with other conditions ceteris paribus, it is known that coefficient (slope) of stock selection ability on Y2 modeling is smaller than in Y1 modeling (with a ratio of almost 1 to 2). This means that the effect of stock selection ability on mutual fund performance is stronger on the Treynor Measure model compared to Sharp Ratio. Further studies are needed regarding systematic risk and unsystematic risk in relation to mutual funds to obtain a well-diversified portfolio.

The results of this research indicate that fund size does not affect the equity mutual funds' performance both in Y1 and Y2 modeling. This finding does not support the presentation of Ciccotello and Grant [18] and research result which states that equity mutual funds' performance is positively affected by the size of assets under management of mutual funds [19]. However, this research result is in line with the research of See and Jusoh [27] and 
Ahmad et al [9], both show that the fund size and the fund age do not have a positive effect on equity mutual funds' performance.

\section{Conclusion}

The results of this study shows that : (1) the ability of investment managers to conduct stock selection has a positive and significant effect on the performance of equity mutual fund as measured by Treynor Measure and Sharpe Ratio, (2) the ability of investment managers in terms of market timing shows a negative and significant effect on mutual fund performance as measured by Treynor Measure or Sharpe Ratio, (3) the age characteristics of mutual funds have a significant negative effect on mutual fund performance as measured by Sharpe Ratio, but no significant effect to equity mutual funds' performance as measured by Treynor Measure and (4) the characteristics of mutual funds in terms of fund size does not affect equity mutual funds' performance as measured by Treynor Measure or Sharpe Ratio. The four independent variables collectively affect equity mutual funds' performance. Although the ability to explain Treynor Measure model is higher than Sharpe Ratio model, accordingly need for more independent variables to explain the variability in equity mutual funds' performance using the Sharpe Ratio approach.

Referring to this research results, investors who want to invest in equity funds should pay attention to stock selection and market timing abilities of investment managers who manage a mutual fund and need to consider the age of equity funds if they consider systematic and nonsystematic risks in choosing mutual funds. Meanwhile, investment management companies that manage mutual funds should pay attention and improve the ability of their investment management teams through ongoing training programs, both the ability of stock selection and market timing. Next researchers can conduct similar research on other types of mutual funds or can add other independent variables that affect mutual fund performance, such as economic conditions. Future research can use market timing ability measurements with conditional models or can conduct further research on systematic risk and unsystematic risk in relation to mutual funds to obtain a well-diversified portfolio.

\section{References}

[1] J. P. Meltzer, "Investment," in Bilateral and Regional Trade Agreements: Commentary and Analysis, 2015.

[2] M. Choudhry, D. Joannas, R. Pereira, and R. Pienaar, Capital Market Instruments. 2005.

[3] A. Kurniasih and L. D. Y. Johannes, "ANALISIS VARIABEL MAKROEKONOMI TERHADAP KINERJA REKSADANA CAMPURAN,” J. Manaj., 2017, doi: 10.24912/jm.v19i1.110

[4] I. Omisore, "The modern portfolio theory as an investment decision tool," J. Account. Tax., 2012, doi: 10.5897/jat11.036.

[5] H. Markowitz, "Portfolio Selection Harry," J. ofFinance, Vol. 7, No. 1. (Mar., 1952), pp. 77-91. Stable, 1952.

[6] K. C. Reilly, Frank K., Brown, "Investment analysis portfolio management," J. Chem. Inf. Model., 2019.

[7] J. TREYNOR and K. MAZUY, "Can mutual funds outguess the market?," Harv. Bus. Rev., 1966.

[8] R. D. Henriksson, "Market Timing and Mutual Fund Performance: An Empirical Investigation," J. Bus., 1984, doi: 10.1086/296225. 
[9] Y. Ahmad, G. Sun, and W. Bin Khidmat, "Fund-Specific Determinants of Performance: An Empirical Study of Islamic and Conventional Mutual Funds of Pakistan," Int. J. Econ. Financ. Issues, 2017.

[10] S. Naveen and T. Mallikarjunappa, "An Empirical Study on Market Timing and Selectivity Skills of Indian Mutual Fund Managers Using Treynor and Mazuy Model," Int. J. Comput. Res. Dev., 2016.

[11] L. Oliveira, T. Salen, J. D. Curto, and N. Ferreira, "Market Timing and Selectivity: An Empirical Investigation of European Mutual Fund Performance," Int. J. Econ. Financ., 2018, doi: $10.5539 /$ ijef.v11n2p1.

[12] J. Gao, N. O'Sullivan, and M. Sherman, "The Market-Timing Ability of Chinese Equity Securities Investment Funds," SSRN Electron. J., 2017, doi: 10.2139/ssrn.3054429.

[13] Gusni, Silviana, and F. Hamdani, "Factors affecting equity mutual fund performance: Evidence from Indonesia," Invest. Manag. Financ. Innov., 2018, doi: 10.21511/imfi.15(1).2018.01.

[14] J. A. Busse and Q. Tong, "Mutual fund industry selection and persistence," Review of Asset Pricing Studies. 2012, doi: 10.1093/rapstu/ras004.

[15] K. Cuthbertson and D. Nitzsche, "Performance, stock selection and market timing of the German equity mutual fund industry," J. Empir. Financ., 2013, doi: 10.1016/j.jempfin.2012.12.002.

[16] C. F. Dharmastuti and B. Dwiprakasa, "KARAKTERISTIK REKSA DANA DAN KINERJA REKSA DANA SAHAM DI INDONESIA,” J. Ekon., 2017, doi: 10.24912/je.v22i1.181.

[17] S. Goel, M. Mani, and R. Sharma, "a Review of Performance Indicators of Mutual Funds," $J$. Arts, Sci. Commer., 2012.

[18] C. Ciccotello, "Equity fund size and growth: Implications for performance and selection," Financ. Serv. Rev., 1996, doi: 10.1016/s1057-0810(96)90023-2.

[19] M. A. Ferreira, A. Keswani, A. F. Miguel, and S. B. Ramos, "The Determinants of mutual fund performance: A cross-country study," Rev. Financ., 2013, doi: 10.1093/rof/rfs013.

[20] R. Lonkani, T. Satjawathee, and K. Jegasothy, "Selectivity and Market Timing Performance in a Developing Country's Fund Industry: Thai Equity Funds Case," J. Appl. Financ. Bank., 2013.

[21] V. S. Paramita, F. M. Sembiring, and D. Safitri, "Measuring Selectivity and Market Timing Performance of Mutual Funds in Indonesia Using Single and Dual Beta Models," KnE Soc. Sci., 2018, doi: 10.18502/kss.v3i10.3515.

[22] R. D. Henriksson and R. C. Merton, "On Market Timing and Investment Performance. II. Statistical Procedures for Evaluating Forecasting Skills,” J. Bus., 1981, doi: 10.1086/296144.

[23] J. Chen, H. Hong, M. Huang, and J. D. Kubik, "Does fund size erode mutual fund performance? The role of liquidity and organization," Am. Econ. Rev., 2004, doi: $10.1257 / 0002828043052277$.

[24] A. Hamzah and A. Yohanes, "ANALISIS PERBANDINGAN KINERJA REKSA DANA SYARIAH DENGAN REKSA DANA KONVENSIONAL JENIS SAHAM PADA PERIODE 2008 - 2012," Mix J. Ilm. Manaj., 2014.

[25] "MARKET TIMING ABILITY OF MUTUAL FUNDS WITH TESTS APPLIED ON SEVERAL CROATIAN FUNDS," Croat. Oper. Res. Rev., 2013.

[26] M. Jaksic, M. Lekovic, and M. Milanovic, "Measuring the performance of mutual funds: A case study," Industrija, 2015, doi: 10.5937/industrija43-6677.

[27] Y. See and R. Jusoh, "Fund characteristics and fund performance: Evidence of Malaysian mutual funds," Management, 2012. 